\title{
Use of metallurgical dust for removal chromium ions from aqueous solutions
}

\author{
Magdalena Pająk ${ }^{1, *}$, Agnieszka Dzieniszewska ${ }^{1}$, Joanna Kyzioł-Komosińska ${ }^{1}$ and Michat \\ Chrobok $^{1}$ \\ ${ }^{1}$ Institute of Environmental Engineering Polish Academy of Science, 41-819 Zabrze, $34 \mathrm{M}$. \\ Skłodowskiej-Curie Street, Poland
}

\begin{abstract}
The aim of the study was to determine the potential for the application of dust from steel plant as an effective sorbent for removing $\mathrm{Cr}(\mathrm{III})$ and $\mathrm{Cr}(\mathrm{VI})$ in the form of simple and complex ions - Acid Blue 193 dye from aqueous solutions. Three isotherms models were used to interpret the experimental results namely: Langmuir, Freundlich, and DubininRadushkevich. Estimated equations parameters allowed to determine the binding mechanism. Based on laboratory studies it was found that the dust was characterized by high sorption capacities for $\mathrm{Cr}$ ions and dye from the aqueous solution. The sorption capacity of the dust for $\mathrm{Cr}(\mathrm{III})$ and $\mathrm{Cr}(\mathrm{VI})$ ions depended on the degree of oxidation, $\mathrm{pH}$ of solution and kind of anion and changed in series: $\mathrm{Cr}(\mathrm{III})-\mathrm{Cl} \mathrm{pH}=5.0>\mathrm{Cr}(\mathrm{III})-\mathrm{SO}_{4} \mathrm{pH}=5.0>\mathrm{Cr}(\mathrm{III})-\mathrm{Cl}$ $\mathrm{pH}=3.0>\mathrm{Cr}(\mathrm{III})-\mathrm{SO}_{4} \mathrm{pH}=3.0>\mathrm{Cr}(\mathrm{VI}) \mathrm{pH}=5.0>\mathrm{Cr}(\mathrm{VI}) \mathrm{pH}=3.0$. Dust was also characterized by a high maximum sorption capacity of dye at a range of $38.2-91.7 \mathrm{mg} / \mathrm{g}$, depending on the dose of dust. Based on the study it was found that dust from a steel plant, containing iron oxides, can be used as low-cost and effective sorbent to remove pollutions containing chromium ions, especially from acidic wastewater.
\end{abstract}

\section{Introduction}

Among the different pollutants of an aquatic ecosystem, dyes are a large and important group of industrial chemicals. They are originated from dyeing process in: textile, cosmetic, paper and leather industries [1-3]. Metal-complex dyes, often used in the dyeing process, contain in their structure chromium ions which are bound in the form of complex ions. This dyes are water-soluble, have high light stability and wet properties. Unused dyes and auxiliary substances, such as hexavalent chromium ions, enter the environment along with wastewater.

Chromium species exist in water in two different oxidation states: $\mathrm{Cr}(\mathrm{VI})$ and $\mathrm{Cr}(\mathrm{III})$. Both forms of chromium differ considerably in chemical properties and environmental impact. Trivalent chromium is a nutrient and essential microelement at trace levels, on the other hand hexavalent forms of chromium are highly toxic and carcinogenic. Depending on the source (kind of industry), chromium in wastewater occurs as strongly hydrated cations $\left[\mathrm{Cr}\left(\mathrm{H}_{2} \mathrm{O}\right)_{6}\right]^{3+}$, as anions $\mathrm{Cr}_{2} \mathrm{O}_{7}{ }^{2-}$ or $\mathrm{HCrO}_{4}^{-}$(galvanic, textile wastes) or as complexed

\footnotetext{
${ }^{*}$ Corresponding author: magdalena.pajak@ipis.zabrze.pl
} 
neutral, anionic or cationic compounds (textile dyeing wastes) [4]. According to current Polish legislative regulations of the Ministry of the Environment the concentrations of the $\mathrm{Cr}(\mathrm{VI})$ ions and total $\mathrm{Cr}$ in sewage introduced into water should be lower than $0.05-0.5$ $\mathrm{mg} / \mathrm{L}$ and $0.5-1.0 \mathrm{mg} / \mathrm{L}$, respectively. Due to low concentration limit for chromium ions in wastewater, it is necessary to eliminate it thoroughly from contaminated effluents. Several treatment technologies have been developed to remove chromium from water and wastewater. The common methods include chemical precipitation, ion exchange, membrane separation, sedimentation, and adsorption [5,6]. Adsorption onto activated carbon is effective in the removal of contaminants from wastewater at a wide range of them but its regeneration after the use is troublesome [2, 7-9]. Due to the inability to widely used, arises the need of searching the cost effective substitutes with high sorption capacity. Such sorbents are: clays, peat, brown coal, zeolites, composts and metallurgical wastes [10-16].

Residue such as dusts and sludges that originate from steel plants in course of steel production are only partially recycle. Its chemical composition, including high iron content that suggests possibility of application as sorbent for chromium ions $[15,16]$.

The aim of this study was to determine the sorption capacity of metallurgical dust for the $\mathrm{Cr}(\mathrm{III}), \mathrm{Cr}(\mathrm{VI})$ ions and metal-complex dye - Acid Blue 193, as well as determining the most efficient and economical (by minimizing the sorbent treatment) process conditions. Moreover, using the nonlinear sorption isotherms the values of parameters in the Freundlich, Langmuir and Dubinin-Radushkevich sorption equations were estimated.

\section{Materials and methods}

\subsection{Research materials}

Dust from de-dusting of sintering belt obtained from steel plant was used for laboratory studies. Dust contained high amount of iron compounds $(\mathrm{Fe}-51.66 \%, \mathrm{FeO}-6.07 \%$, Table 1). Presence of calcium oxide contribute to high $\mathrm{pH}$ in water suspension $(\mathrm{pH}=10.11)$ and high buffer capacity (plot not included) indicating potential to counteract $\mathrm{pH}$ changes, for example in reaction with acidic solutions.

Table 1. Chemical composition.

\begin{tabular}{|c|c|c|c|c|c|c|c|c|c|c|}
\hline $\mathbf{F e}$ & $\mathbf{F e O}$ & $\mathrm{SiO}_{2}$ & $\mathbf{C a O}$ & $\mathbf{M g O}$ & $\mathbf{A l}_{2} \mathbf{O}_{3}$ & $\mathbf{M n}$ & $\mathbf{N a}_{2} \mathbf{O}$ & $\mathbf{K}_{2} \mathbf{O}$ & $\mathbf{Z n}$ & $\mathbf{S}$ \\
\hline 51.66 & 6.07 & 7.02 & 7.72 & 1.45 & 1.45 & 0.34 & 0.14 & 0.15 & 0.07 & 0.18 \\
\hline
\end{tabular}

Sorption studies were carried out using metal-complex dye - Acid Blue 193 (AB-193) and $\mathrm{Cr}(\mathrm{III})$ and $\mathrm{Cr}(\mathrm{VI})$ ions.

Figure 1 shows the characteristics of the Acid Blue 193 dye: structural formula of dye, CAS number, molecular formula, molecular weight, wave length at which concentrations were measured and $\mathrm{pH}$ value in water at $1 \mathrm{~g} / \mathrm{L}$.

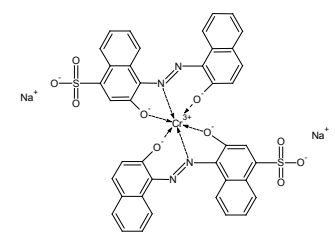

CAS: $12392-64-2$

C40-H22-Cr-N4-O10-S2.2Na

M $880.7 \mathrm{~g} / \mathrm{mol}$

pH 6.70

Fig. 1. Characteristics of Acid Blue 193 dye. 
Chromium (III) ions solution was prepared by dissolving $\mathrm{CrCl}_{3} \cdot 6 \mathrm{H}_{2} \mathrm{O}$ or $\mathrm{KCr}\left(\mathrm{SO}_{4}\right)_{2} \cdot 12 \mathrm{H}_{2} \mathrm{O}$ in water. Solution of chromium (VI) ions was prepared by dissolving $\mathrm{K}_{2} \mathrm{CrO}_{4}$.

\subsection{Methods}

\subsubsection{Sorption process}

Laboratory experiments on sorption of metal-complex dye and $\mathrm{Cr}(\mathrm{III})$ and $\mathrm{Cr}(\mathrm{VI})$ were carried out under the batch method at room temperature, contact time of the solid phase (S) to the solution $(\mathrm{L})-24$ hours, the initial concentrations of dye within the range $1-1000$ $\mathrm{mg} / \mathrm{L}$, and of $\mathrm{Cr}$ ions $0.1-1000 \mathrm{mg} / \mathrm{L}$, the solid phase to the solution ratio for AB-193 dye 1:50, 1:100, 1:200, for $\mathrm{Cr}$ ions 1:100, and the $\mathrm{pH}$ in the $\mathrm{Cr}(\mathrm{III})$ and $\mathrm{Cr}(\mathrm{VI})$ stock solutions 3.0 or 5.0 adjusted using $0.1 \mathrm{M} \mathrm{KOH}$ and $0.1 \mathrm{M} \mathrm{H}_{2} \mathrm{SO}_{4}$, respectively.

The initial $\left(\mathrm{C}_{0}\right)$ and equilibrium $\left(\mathrm{C}_{\mathrm{eq}}\right)$ concentrations of the dye were determined using UV-vis spectrometry (Spectrometer Varian Cary 50 Scan UV-VIS) and $\mathrm{Cr}$ ions concentrations were determined by atomic absorption spectrophotometry (Spectra 200, Varian).

Amount of dye and $\mathrm{Cr}$ ions adsorbed (q) by the used sorbent was calculated from the formula:

$$
q=\left(C_{0}-C_{e q}\right) \cdot \frac{V}{m}
$$

where: $\mathrm{m}$ - sorbent mass ( $\mathrm{g}), \mathrm{V}$ - solution volume (L).

Percentage pollutions removal $(\mathrm{R})$ was calculated from the formula:

$$
R=\frac{C_{0}-C_{e q}}{C_{0}} \cdot 100 \%
$$

\subsubsection{Determination of parameters in sorption isotherms}

In order to estimate sorbent maximum sorption capacity and to determine the mechanism of the binding of the dye and $\mathrm{Cr}$ ions, three isotherm equations were used: Freundlich, Langmuir and Dubinin-Radushkevich.

Freundlich Isotherm of the formula [17]:

$$
q=K_{F} \cdot C_{e q}^{1 / n}
$$

where: $K_{F}-$ Freundlich isotherm constant $\left((\mathrm{mg} / \mathrm{g}) \cdot(\mathrm{L} / \mathrm{mg})^{1 / \mathrm{n}}\right), 1 / \mathrm{n}-$ measure of surface heterogeneity (the higher the $1 / \mathrm{n}$ value, the more favorable the adsorption).

Langmuir Isotherm represented by the following equation [18]:

$$
q=\frac{Q K_{L} C_{e q}}{1+K_{L} C_{e q}}
$$

where: $\mathrm{Q}$ - maximum sorption capacity relative to dye/Cr ions $(\mathrm{mg} / \mathrm{g}), \mathrm{K}_{\mathrm{L}}$ - Langmuir isotherm constant $(\mathrm{L} / \mathrm{mg})$.

Dubinin-Radushkevich Isotherm represented by the equation:

$$
q=q_{D} \cdot \exp \left(-\beta \varepsilon^{2}\right)
$$

where: $\mathrm{q}_{\mathrm{D}}$ - the sorption capacity of studied dust for dye/Cr ions (mmol/g), $\beta$ - the constant $\left(\mathrm{mol}^{2} / \mathrm{J}^{2}\right), \varepsilon$ is the Polanyi potential $(\mathrm{J} / \mathrm{mol})$, which is equal to:

$$
\varepsilon=R T \ln \left(1+\frac{1}{C_{e q}}\right)
$$


where: $\mathrm{R}$ - gas constant $(8.314 \mathrm{~J} / \mathrm{mol} \cdot \mathrm{K}), \mathrm{T}$ - absolute temperature $(\mathrm{K})$.

The $\beta$ constant was used to determine the free energy (E) of the adsorption:

$$
E=\frac{1}{(2 \beta)^{1 / 2}}
$$

The $\mathrm{E}$ value indicates that it is ion exchange adsorption $(8<\mathrm{E}<16 \mathrm{~kJ} / \mathrm{mol})$, or physical adsorption $(\mathrm{E}<8 \mathrm{~kJ} / \mathrm{mol})$ [19].

To determine the values of parameters in the sorption isotherms the nonlinear regression method was used (Statistica ver. 9.0). Apart from determination coefficient four different error functions of non-linear regression basin were employed in this study to find out the most suitable isotherm models to represent the experimental data [20]:

$$
\begin{array}{ll}
\text { the sum of the errors square } & S S E=\Sigma\left(q_{\text {cal }}-q_{\text {meas }}\right)^{2} \\
\text { nonlinear chi square test } & \chi^{2}=\sum \frac{\left(q_{\text {cal }}-q_{\text {meas }}\right)^{2}}{q_{\text {meas }}}
\end{array}
$$

where: $\mathrm{q}_{\mathrm{cal}}$ - calculated, $\mathrm{q}_{\text {meas }}-$ measured.

\section{Study results and discussion}

\subsection{Sorption of Acid Blue 193 dye onto dust}

Figure 2 shows experimental sorption isotherms for steel plant dust and the percentage removal Acid Blue 193 from aqueous solutions, depending on the ratio of solid phase (S) to solution (L).

The results showed that at a ratio of $\mathrm{S}: \mathrm{L}=1: 50$ (dust dosage $20 \mathrm{~g} / \mathrm{L}$ ) AB-193 dye was completely bound, at the initial concentration ranging from $1-100 \mathrm{mg} / \mathrm{L}$, sorption capacity changed in a range $0.0545-4.96 \mathrm{mg} / \mathrm{g}$. At the ratio of $\mathrm{S}$ : $\mathrm{L}=1: 100$ (dust dosage of $10 \mathrm{~g} / \mathrm{L}$ ) and 1:200 (dust dosage of $5 \mathrm{~g} / \mathrm{L}$ ) dye was completely bound only at concentration equal 1 $\mathrm{mg} / \mathrm{L}$. As the initial concentration increased, the sorption capacity of the dust increased.

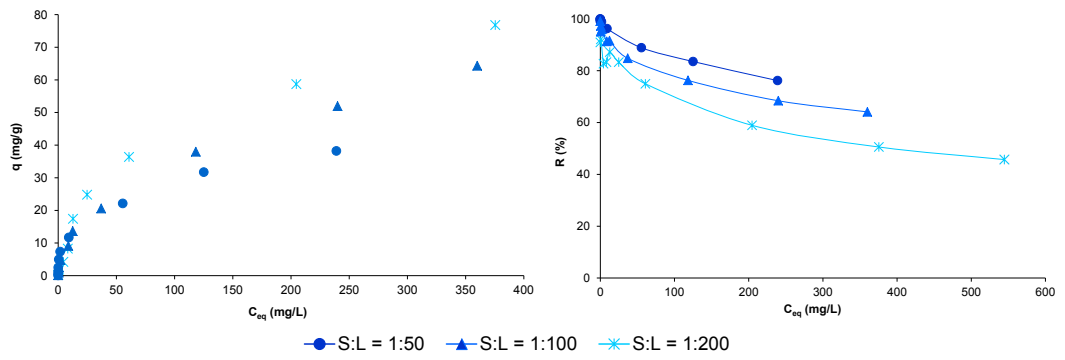

Fig. 2. Experimental sorption isotherms and the percentage removal from aqueous solutions of AB193 dye on dust.

At the maximum initial concentration of $1000 \mathrm{mg} / \mathrm{L}$ and the ratio $\mathrm{S}: \mathrm{L}=1: 50 \mathrm{AB}-193$ dye was bound in an amount of $38.2 \mathrm{mg} / \mathrm{g}$, in the ratio $\mathrm{S}: \mathrm{L}=1: 100$ and 1:200 were bound in an amount $64.31 \mathrm{mg} / \mathrm{g}$ and $91.7 \mathrm{mg} / \mathrm{g}$, respectively. With the increase of the dye initial concentration in the solution and the decrease the dosage of dust, it was observed a reduction of the degree its removal from the solution (removal efficiency). At the maximum dye initial concentration in solution, the removal rate was $76.17 \%, 64.11 \%$ and $45.71 \%$, respectively. The trend indicates that the sorbent percentage was proportional to the sorbent mass and was in agreement with the formula: 


$$
R=\frac{q \cdot m}{C_{0} \cdot V} \cdot 100 \%
$$

obtained by transforming Eq. 1 and substituting it in Eq. 2 .

Sorption process of the AB-193 dye was carried out at practically constant $\mathrm{pH}$ values in the range of $12.75-13.02$.

Genc and Oguz [16] were carried out studies on the removal of metal-complex dyes containing chromium using metallurgical wastes. Scientists have found much worse research results (such as $\mathrm{q}=3.2 \mathrm{mg} / \mathrm{g}$ for Acid Yellow 99, $\mathrm{q}=0.6 \mathrm{mg} / \mathrm{g}$ for Acid Red 183) under the same conditions of sorption (such as $\mathrm{S}: \mathrm{L}=1: 100, \mathrm{C}_{0}=100 \mathrm{mg} / \mathrm{L}$ ).

By comparing the sorption capacity and the removal rate of AB-193 dye depending on the ratio solid phase to the solution $(\mathrm{S}: \mathrm{L})$, it was found that the most favorable conditions of its binding are at $\mathrm{S}: \mathrm{L}=1: 100$ (Fig. 3). Therefore, it was decided that the $\mathrm{Cr}$ ions sorption studies would be carried out only at the ratio S:L equal 1:100.

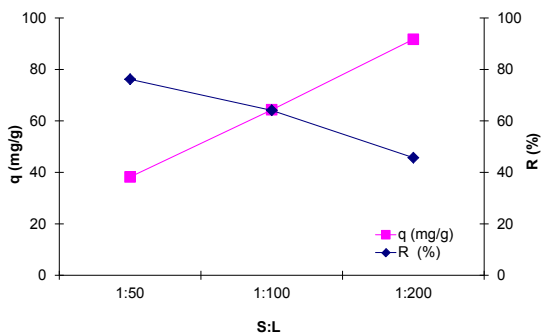

Fig. 3. Sorption (q) and removal efficiency (R) of AB-193 as a function dust dose.

\subsection{Sorption of chromium (III) and (VI) onto dust}

Figure 4 shows experimental sorption isotherms and the percentage removal from aqueous solutions of chromium (III) and (VI) on dust.

It was found that the sorption course and the sorption capacity depended on the degree of oxidation of $\mathrm{Cr}$ ions, $\mathrm{pH}$ of the solution, type of anion in solution, and decreases in following order: $\mathrm{Cr}(\mathrm{III})-\mathrm{Cl} \mathrm{pH}=5.0>\mathrm{Cr}(\mathrm{III})-\mathrm{SO}_{4} \mathrm{pH}=5.0>\mathrm{Cr}(\mathrm{III})-\mathrm{Cl} \mathrm{pH}=3.0>\mathrm{Cr}(\mathrm{III})-$ $\mathrm{SO}_{4} \mathrm{pH}=3.0>\mathrm{Cr}(\mathrm{VI}) \mathrm{pH}=5.0>\mathrm{Cr}(\mathrm{VI}) \mathrm{pH}=3.0$.

The sorption capacity of $\mathrm{Cr}(\mathrm{III})$ ions from chloride solution at $\mathrm{pH} 5.0$ and at initial ions concentration in range $0.1-990 \mathrm{mg} / \mathrm{L}$ increased from 0.0079 to $98.8 \mathrm{mg} / \mathrm{g}$. The removal efficiency of $\mathrm{Cr}(\mathrm{III})$ ions in the studied range of solutions was steady at $99.90 \%$. The sorption process was carried out at high $\mathrm{pH}$ value of the equilibrium solution in the range of 9.4 - 7.4. High solution $\mathrm{pH}$ indicate that $\mathrm{Cr}$ ions precipitate in form of $\mathrm{Cr}(\mathrm{OH})_{3}$.

$\mathrm{Cr}$ (III) ions from sulfate solutions at $\mathrm{pH} 5.0$ were bonded by dust in lower amounts than from chloride solutions. The sorption capacity varied from 0.018 to $62.0 \mathrm{mg} / \mathrm{g}$. In the concentration range of 0.1 to $500 \mathrm{mg} / \mathrm{L}$, the removal of $\mathrm{Cr}(\mathrm{III})$ ions from the solution was at a constant level of $99.99 \%$ and the equilibrium concentration the $\mathrm{pH}$ in the solution varied from 8.0 to 7.4, which also indicates the possibility of $\mathrm{Cr}(\mathrm{OH})_{3}$ precipitation. The maximum sorption capacity of dust was $62.0 \mathrm{mg} / \mathrm{g}$, and a removal efficiency $-69.66 \%$.

At solution of initial $\mathrm{pH}=3.0$ decrease in sorption capacity, for $\mathrm{Cr}$ (III) ions, occurs both in chloride and sulfate solution. Sorption from chloride solutions varied in the range of $0.0138-38.0 \mathrm{mg} / \mathrm{g}$ and from sulfate solutions $-0.0109-23.0 \mathrm{mg} / \mathrm{g}$, while the degree of removal $\mathrm{Cr}$ (III) ions from the solutions in the range of $99.0-36.19 \%$ and $99.0-21.29 \%$, respectively. Sorption process of $\mathrm{Cr}(\mathrm{III})$ was carried out at practically similar $\mathrm{pH}$ values in the range of $9.0-3.54$ and $9.0-3.80$, respectively. At the same time it was found that, in 
initial concentration range from 0.1 to $100 \mathrm{mg} / \mathrm{L}$, ions from both solutions were sorbed completely and solution $\mathrm{pH}$ was above 7.5.

In the experiment $\mathrm{CrCl}_{3} \cdot 6 \mathrm{H}_{2} \mathrm{O}$ and $\mathrm{KCr}\left(\mathrm{SO}_{4}\right)_{2} \cdot 12 \mathrm{H}_{2} \mathrm{O}$ were used and values of $\mathrm{pH}$ of the stock solutions were 2.76 and 3.05 , respectively. For adjustment $\mathrm{pH}$ solution to values 5.0 and 3.0 were used $0.1 \mathrm{M} \mathrm{KOH}$ solution. $\mathrm{K}^{+}$ions were in competition for sorption centres with $\mathrm{Cr}(\mathrm{III})$ and $\mathrm{H}^{+}$ions mainly at higher concentration of $\mathrm{Cr}$ (III) ions. Presence of $\mathrm{K}^{+}$ions reduce of sorption capacity of dust for $\mathrm{Cr}$ (III) and maximum sorption capacity was considerably higher for chloride than sulfate solution.

Studied dust has high buffer capacity and suspension $\mathrm{pH}$ due to calcium oxide presence. Hence $\mathrm{pH}$ in equilibrium solutions was higher than in starting solutions. Moreover $\mathrm{pH}$ above 5.0 causes $\mathrm{Cr}$ precipitate in form of $\mathrm{Cr}(\mathrm{OH})_{3}$.

Presence of $\mathrm{Fe}$ compounds in dust causes that $\mathrm{Cr}(\mathrm{III})$ ions can be bound by hydrated iron oxides in the reaction $3 \mathrm{FeO}(\mathrm{OH})+\mathrm{Cr}^{3+}=(\mathrm{FeOO}){ }_{3} \mathrm{Cr}+3 \mathrm{H}^{+}$.

Dust sorbed $\mathrm{Cr}(\mathrm{VI})$ ions in smaller quantities in corresponds to $\mathrm{Cr}(\mathrm{III})$ ions. From solutions of $\mathrm{pH} 5.0$ they were sorbed in range 0.008 to $18.0 \mathrm{mg} / \mathrm{g}$ and from solutions of $\mathrm{pH}$ 3.0 from 0.012 to $16.0 \mathrm{mg} / \mathrm{L}$, no influence of solution $\mathrm{pH}$ upon dust sorption capacity was found. Removal degree of ions from solution changes in following order $90.0-18.0 \%$ and $90.0-16.0 \%$, respectively. Sorption of $\mathrm{Cr}(\mathrm{VI})$ ions occurred at similar $\mathrm{pH} 9.22-6.99$.

Iron oxide belongs to compounds of high point of zero net charge $\left(\mathrm{pH}_{\mathrm{PZC}}>8.0\right)$ value, which is defined as the $\mathrm{pH}$ at which the charge of the colloidal particles is equal to zero. The minerals are positively charged due to the protonation of the surface when the solution $\mathrm{pH}$ is lower than their $\mathrm{pH}_{\mathrm{PZC}}$ values and negatively charged due to the deprotonation of the surface when the solution $\mathrm{pH}$ is higher than the $\mathrm{pH}_{\mathrm{PZC}}$. Hence iron compounds at $\mathrm{pH}$ below 8.0 have positively charged surface and can bond anionic contaminants $\left(\mathrm{Cr}_{2} \mathrm{O}_{7}^{2-}\right)$ or anionic dyes.

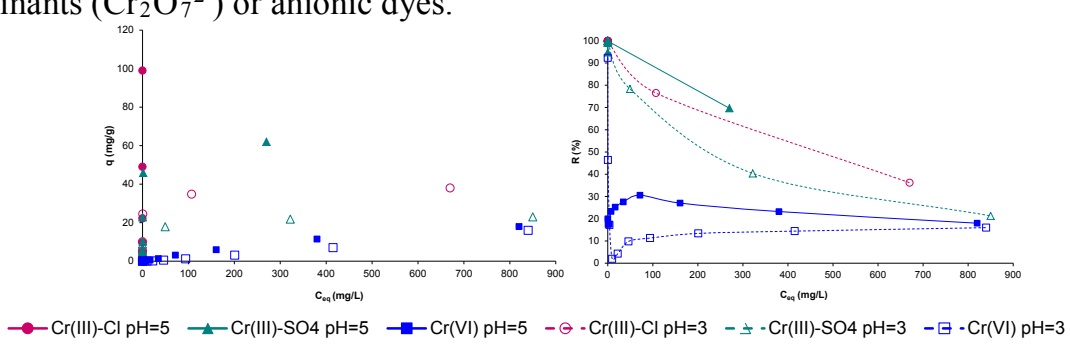

Fig. 4. Sorption isotherms and the percentage removal of $\mathrm{Cr}(\mathrm{III})$ and (VI) for studied dust.

\subsection{Freundlich, Langmuir and Dubinin-Radushkevich adsorption isotherm models}

The isotherm parameters for all the models studied along with correlation coefficient $\mathrm{R}^{2}$ and values of error for functions of non-linear regression are listed in Table 2. The plots of the experimental data and the predicted data from Langmuir, Freundlich and DubininRadushkevich (D-R) isotherm models of studied dust are shown in Figure 5.

The $\mathrm{R}^{2}$ values suggest that the all isotherms provide a good models of the sorption of AB-193 on metallurgical dust. Values of $1 / \mathrm{n}$ less than 1 in Freundlich isotherm show the favorable nature of adsorption of AB-193 on dust for all S:L ratio. The saturated monolayer sorption capacity, $\mathrm{q}_{\max }$ for dye, were higher than the experimental values. At the same time, the D-R isotherm model also well described the AB-193 sorption onto dust. The mean free energy values (E) for adsorption of dye onto dust were above $8.0 \mathrm{~kJ} / \mathrm{mol}$ and indicate that the sorption process had an ion-exchange character. On the other hand Langmuir and D-R 
isotherm exhibited lower SSE and $\chi^{2}$ values then Freundlich considered to be a better fit compared to the Langmuir and D-R isotherms.

Table 2. Parameters of sorption isotherms estimated on Freundlich, Langmuir and DubininRadushkevich models.

\begin{tabular}{|c|c|c|c|c|c|c|c|c|c|}
\hline & \multicolumn{2}{|c|}{$\mathrm{Cr}(\mathrm{III})-\mathrm{Cl}$} & \multicolumn{2}{|c|}{$\mathrm{Cr}(\mathrm{III})-\mathrm{SO}_{4}$} & \multicolumn{2}{|c|}{$\operatorname{Cr}(\mathrm{VI})$} & \multicolumn{3}{|c|}{ Acid Blue 193} \\
\hline & $\mathrm{pH}=5$ & $\mathbf{p H}=\mathbf{3}$ & $\mathbf{p H}=\mathbf{5}$ & $\mathbf{p H}=\mathbf{3}$ & $\mathbf{p H}=\mathbf{5}$ & $\mathbf{p H}=\mathbf{3}$ & 1:50 & 1:100 & $1: 200$ \\
\hline \multicolumn{10}{|c|}{ Freundlich isotherm } \\
\hline $1 / \mathrm{n}$ & 2.40 & 0.2161 & 0.1774 & 0.1804 & 0.7133 & 0.8670 & 0.3564 & 0.4959 & 0.6628 \\
\hline $\mathrm{K}_{\mathrm{F}}$ & 10785 & 19.52 & 13.25 & 7.4055 & 0.1537 & 0.00617 & 5.478 & 3.470 & 1.440 \\
\hline $\mathrm{R}^{2}$ & 0.9930 & 0.7556 & 0.8471 & 0.9046 & 0.9942 & 0.9998 & 0.9975 & 0.9984 & 0.9967 \\
\hline SSE & 84.76 & 284.4 & 323 & 43.7 & 1.93 & 1.04 & 4.20 & 7.20 & 32.02 \\
\hline$\chi^{2}$ & 44.52 & 331.8 & 742.6 & 124.62 & 1.95 & 0.51 & 0.84 & 1.29 & 1.61 \\
\hline \multicolumn{10}{|c|}{ Langmuir isotherm } \\
\hline$q_{\text {exp. }}$ & 98.99 & 38.00 & 62.00 & 23.00 & 18.00 & 16.00 & 38.20 & 64.30 & 91.70 \\
\hline Q & \multirow{5}{*}{ 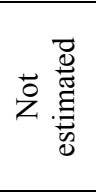 } & 63.17 & 36.23 & 24.94 & 35.22 & 45.34 & 40.22 & 78.18 & 171.6 \\
\hline $\mathrm{K}_{\mathrm{L}}$ & & 1.1523 & 4.033 & 12.81 & 0.00128 & 0.00045 & 0.0332 & 0.0962 & 0.0021 \\
\hline $\mathrm{R}^{2}$ & & 0.8844 & 0.9683 & 0.9277 & 0.9996 & 0.8872 & 0.9542 & 0.9822 & 0.9934 \\
\hline SSE & & 46.79 & 507.6 & 256.4 & 2.15 & 13.87 & 79.22 & 84.96 & 64.15 \\
\hline$\chi^{2}$ & & 7.30 & 65.77 & 108.1 & 2.25 & 4.51 & 12.49 & 7.98 & 7.94 \\
\hline \multicolumn{10}{|c|}{ Dubinin-Radushkevich isotherm } \\
\hline $\mathrm{qD}_{\mathrm{D}}$ & 322.9 & 1.743 & 0.933 & 0.534 & 1.139 & 2.545 & 0.135 & 0.3556 & 0.896 \\
\hline$\beta$ & 0.0107 & 0.0019 & 0.0016 & 0.0016 & 0.0113 & 0.0204 & 0.0028 & 0.0043 & 0.0065 \\
\hline $\mathrm{E}$ & 6.83 & 17.90 & 16.90 & 17.71 & 6.66 & 4.95 & 13.31 & 10.72 & 8.78 \\
\hline $\mathrm{R}^{2}$ & 0.9639 & 0,8191 & 0.9011 & 0.9282 & 0.9995 & 0.9988 & 0.9943 & 0.9979 & 0.9955 \\
\hline SSE & 197.9 & 186.5 & 828.5 & 25.92 & 0.14 & 0.28 & 9.86 & 9.93 & 43.99 \\
\hline$\chi^{2}$ & 167.4 & 121.9 & 498.4 & 90.17 & 0.11 & 0.30 & 3.82 & 1.55 & 4.96 \\
\hline
\end{tabular}

It was determined that $\mathrm{Cr}$ (III) ions sorption, from chloride solution of $\mathrm{pH} 5.0$, cannot be modeled by Langmuir isotherm. However Freundlich and D-R equations well described the sorption process. Values of $1 / \mathrm{n}$ parameter, in Freundlich equation, above 1 indicate precipitation of $\mathrm{Cr}(\mathrm{III})$ ions in form of $\mathrm{Cr}(\mathrm{OH})_{3}$. The $\mathrm{E}$ parameter in D-R isotherm was below $8.0 \mathrm{~kJ} / \mathrm{mol}$ what indicates physical character of sorption.
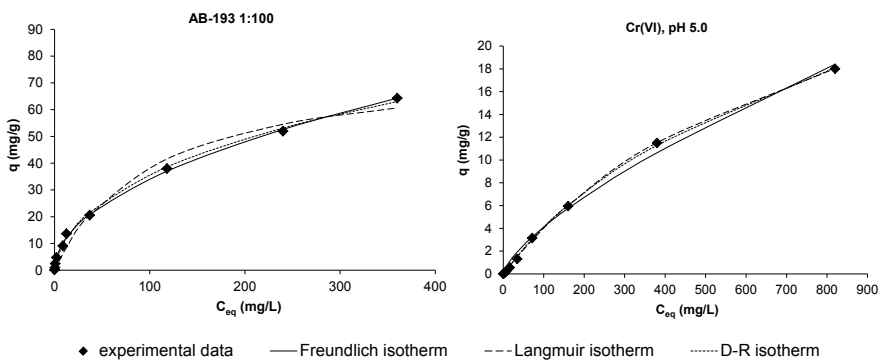

Fig. 5. Comparison of isotherms with experimental data for selected solutions.

From applied models, Langmuir isotherm well described sorption of $\mathrm{Cr}$ (III) ions from chlorides, at $\mathrm{pH} 3.0$ as well as from sulfate solutions at $\mathrm{pH} 3.0$ and 5.0. Correlation coefficient $\mathrm{R}^{2}$ was in range $0.88-0.97$.

All studied isotherm well described the sorption of $\mathrm{Cr}(\mathrm{VI})$ at $\mathrm{pH} 5.0$ and 3.0. Values of $1 / \mathrm{n}$ below 1 show the favorable nature of adsorption and the values of $\mathrm{E}$ parameter below 
$8.0 \mathrm{~kJ} / \mathrm{mol}$ indicate physical character of sorption. Langmuir the saturated monolayer sorption capacity values, Q parameter indicates high sorption properties of dust for $\mathrm{Cr}(\mathrm{VI})$ ions. Value of $\mathrm{Q}$ for sorption at $\mathrm{pH} 3.0$ was higher than the $\mathrm{Q}$ for sorption at $\mathrm{pH}$ 5.0.

\section{Summary}

Conducted studies of sorption capacity of steel plant dust for $\mathrm{Cr}$ ions indicate that sorption capacity depends upon oxidation state, solution $\mathrm{pH}$, as well as anion kind and changes from $99.0-16.0 \mathrm{mg} / \mathrm{g}$ in following order $\mathrm{Cr}$ (III)-Cl pH $=5.0>\mathrm{Cr}(\mathrm{III})-\mathrm{SO}_{4} \mathrm{pH}=5.0>\mathrm{Cr}$ (III)-Cl $\mathrm{pH}=3.0>\mathrm{Cr}(\mathrm{III})-\mathrm{SO}_{4} \mathrm{pH}=3.0>\mathrm{Cr}(\mathrm{VI}) \mathrm{pH}=5.0>\mathrm{Cr}(\mathrm{VI}) \mathrm{pH}=3.0$. Metallurgical dust possess high maximal sorption capacity towards AB-193 dye on level $38.2-91.7 \mathrm{mg} / \mathrm{g}$ depending upon dust dosage.

Studies upon possibility of application of residual dust from steel plants indicate that mentioned dust may be used as effective sorbent for removal of $\mathrm{Cr}(\mathrm{III})$ and $\mathrm{Cr}(\mathrm{VI})$ ions from aqueous solutions including acidic solutions.

The research was conducted at the Institute of Environmental Engineering, Polish Academy of Sciences in Zabrze, as part of the research project UMO-2012/05/N/ST8/03149.

\section{References}

1. M. Wawrzkiewicz, M. Wiśniewska, A. Wołowicz, V. M.Gun'ko, V.I. Zarko, Micropor. Mesopor. Mat. 250, 128 (2017)

2. D. Kołodyńska, J. Krukowska, P. Thomas, Chem. Eng. J. 307, 353 (2017)

3. H.S. Rai, M.S. Bhattacharyya, J. Singh, T.K. Bansal, P. Vats, U.C. Banerjee, Crit. Rev. Env. Sci. Tec. 35, 219 (2005)

4. J. Kyzioł-Komosińska, C. Rosik-Dulewska, A. Dzieniszewska, M. Pająk, I. Krzyżewska, Environ. Prot. Eng. 40, 1, 5 (2014)

5. S. Babel, T.A. Kurniawan, Chemosphere 54, 7, 951 (2004)

6. G. Crini, Bioresource Technol. 97, 1061 (2006)

7. M.T. Yagub, T.K. Sen, S. Afroze, H.M Ang, Adv. Colloid Interface Sci. 209, 172 (2014)

8. V.K. Gupta, Suhas, J. Environ. Manage. 90, 2313 (2009)

9. N. Barka, A. Assabbane, Y. Aît Ichou, A. Nounah, J. Appl. Sci. 6, 3, 692 (2006)

10. I. Chaari, B. Moussi, F. Jamoussi, J. Alloy. Compd. 647, 720 (2015)

11. R. Elmoubarki, F.Z. Mahjoubi, H. Tounsadi, J. Moustadraf, M. Abdennouri, A. Zouhri, A.E. Albani, N. Barka, Water Resources and Industry 9, 16 (2015)

12. Y.S. Ho, G. McKay, Chem. Eng. J. 70, 2, 115 (1998)

13. Y.S. Ho, G. McKay, Process Biochem. 38, 7, 1047 (2003)

14. N. Mirzaei, H.R. Ghaffari, K. Sharafi, A. Velayati, G. Hoseindoost, S. Rezaei, A.H. Mahvi, A. Azari, K. Dindarloo, J. Environ. Chem. Eng. 5, 4, 3151 (2017)

15. C.N.R. Amaral, F.N. Feiteira, R.C. Cruz, V.O. Cravo, R.J. Cassella, W.F. Pacheco, J. Environ. Chem. Eng. 4, 4, 4184 (2016)

16. A. Genc, A. Oguz, Desalination 264, 78 (2010)

17. C. Ng, J.N. Losso, W.E. Marshall, R.M. Rao, Bioresource Technol. 85, 2, 131 (2002)

18. A.O. Dada, A.P. Olalekan, A.M. Olatunya, O. Dada, IOSR-JAC 3, 1, 38 (2012)

19. A. Özcan, E.M. Öncü, A.S. Özcan, Colloid. Surface. A 227, 90 (2006)

20. K.Y. Foo, B.H. Hameed, Chem. Eng. J. 156, 2 (2010) 